
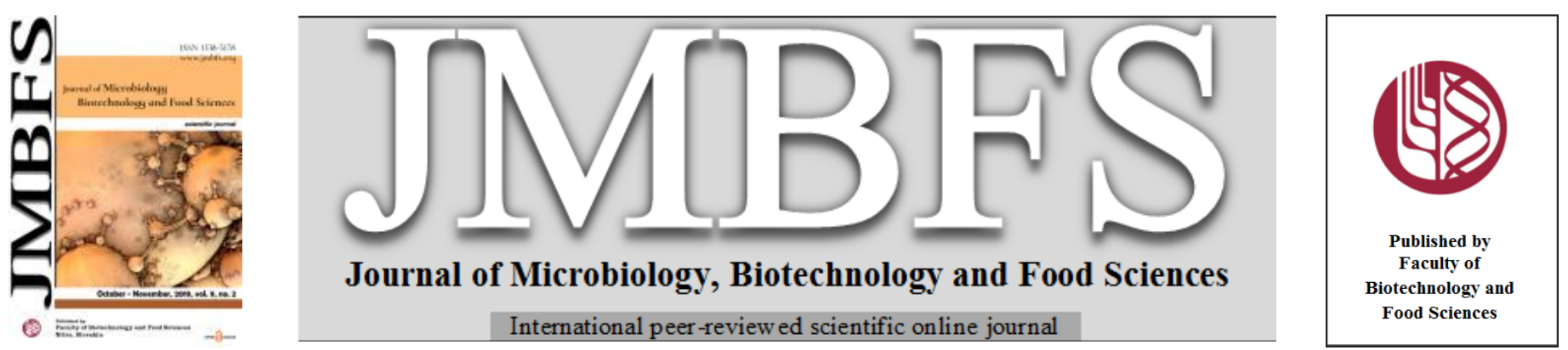

\title{
GIBBERELLIN PRODUCING RHIZOBACTERIA Pseudomonas koreensis MU2 ENHANCE GROWTH OF LETTUCE (Lactuca sativa) AND CHINESE CABBAGE (Brassica rapa, chinensis)
}

\author{
Sang-Mo Kang ${ }^{1}$, Arjun Adhikari ${ }^{2}$, Ko-Eun Lee ${ }^{2}$,Yeon-Gyeong Park ${ }^{2}$, Raheem Shahzad ${ }^{2}$ and In-Jung Lee ${ }^{2}$ * \\ $\operatorname{Address(es):~}$ \\ ${ }^{1}$ Kyungpook National University, Institute of Agricultural Science and Technology, 80 Daehakro, Bukgu, Daegu 41566, Korea. +82 539506776. \\ ${ }^{2}$ Kyungpook National University, School of Applied Biosciences, 80 Daehakro, Bukgu, Daegu 41566, Korea. +82 539505708.
}

*Corresponding author: ijlee@knu.ac.kr

doi: 10.15414/jmbfs.2019.9.2.166-170

\section{ARTICLE INFO}

Received 21. 6. 2018

Revised 25. 3. 2019

Accepted 25. 3. 2019

Published 1. 10. 2019

Regular article

OPEN $\bigodot_{\text {ACCESS }}$

\begin{abstract}
Microbial biofertilizers are considered environmentally safe tool for the healthy production of a plant. Massive application of synthetic pesticides and fertilizers in agriculture has resulted detrimental effect on nature and human health. In the current study, we isolated several strains of rhizoshpheric bacteria through screening from the diversed agricultural soil of Daegu, South Korea. The growth promoting ability of the isolated strains was checked on gibberellin-deficient rice dwarf mutant Waito- $C$, lettuce var. cheongchima and chinese cabbage var. wangmat. The strain having the higher ability to promote the Waito- $c$ growth was selected and further investigation was done. The selected isolate was identified as Pseudomonas koreensis MU2 through 16s rDNA gene sequence analysis. The cultural filtrate analysis revealed that the isolate could produce endogenous phytohormone gibberellic acid (GA1 and GA3) and organic acids, such as citric acid, malic acid, and tartaric acid. Pot experiment revealed that the inoculation of Pseudomonas koreensis MU2 significantly increased shoot length, root length, fresh biomass, and dry biomass of chinese cabbage and lettuce. These results suggest that the Pseudomonas koreensis MU2 might be the possible candidate for bio-fertilizer as a plant growth-promoting rhizobacteria in plant.
\end{abstract}

Keywords: Chinese cabbage, gibberellin, lettuce, organic acid, Pseudomonas koreensis MU2

\section{INTRODUCTION}

Plant root system is the habitat of numerous microbial communities that regulate plant physiology and metabolism (Vurukonda et al., 2016). Plant growthpromoting rhizobacteria act as i) biofertilizer, ii) rhizoremediator, iii) phytostimulator, and iv) stress controller (Lugtenberg and Kamilova, 2009) Bacteria, like Bacillus and Pseudomonas spp., are considered predominant (Podile and Kishore, 2007). Pseudomonas spp., and Bacillus spp., have been widely reported to be involved in the production of enzymes and hormones that alleviate stress, control pathogens, and promote growth and quality yield production (Lucy et al., 2004). Pseudomonas koreensis is a Gram-negative, motile, non-spore-forming, yellow-white, multiple polar flagellated, rod bacterium isolated from farming soil in Korea (Kwon et al., 2003). The type strain is LMG 21318. There is a wide range of plant growth promoting rhizobacteria (PGPR) species like Agrobacterium, Azospirillum, Arthrobacter, Azotobacter, Burkholderia, Caulobacter, Erwinia, Chromobacterium, Flavobacterium, Micrococcous, and Serratia that was reported to improve plant growth and development. (Ahemad and Kibret, 2014).

PGPR has been extensively reported to be involved in endogenous phytohormone production (Maheshwari, 2011) such as gibberellins (Bloemberg and Lugtenberg, 2001; Bottini et al., 2004; Gutiérrez-Mañero et al., 2001). Endogenous hormones possess various plant growth promoting characteristics like flowering initiation, increase in plant height, enhancing seed germination, and mitigating stresses (Kang et al., 2017). Other organic compounds exuded by PGPR include organic acids, amino acids, nucleotides, phenolics, fatty acids, sterols, sugars, vitamins and plant growth regulators (Lugtenberg and Kamilova, 2009). These secondary metabolites, especially organic acids, are involved in metal solubilization (Muleta et al., 2013; Zaidi et al., 2009).

The beneficial impact of plant-microbe interaction has been reported by several authors, like Pseudomonades sp., Bacillus lentus, and Azospirillum improved photosynthetic pigments and antioxidant of basil plant under water stress (Heidari and Golpayegani, 2012). Likewise, Mesorhizobium sp. resist pesticides [herbicides (metribuzin and glyphosate), fungicides (hexaconazole, metalaxyl, and kitazin) insecticides and (imidacloprid and thiamethoxam)] and could promote growth of chickpea (Ahemad and Khan, 2012). Pseudomonas spp., and P. chlororaphis solubilize phosphate and promote the growth of Coffea arabica L (Muleta et al. 2013). Besides these, PGPR also play a key role in mitigating various biotic and abiotic stress-like pathogens (Park et al., 2017), drought (Lim and Kim, 2013), heavy metal (Islam et al., 2014), salt stress (Karlidag et al., 2013), and heat stress (Park et al., 2017). Moreover, the mechanism that involves the beneficial role of PGPR are well documented in the literature (Ahemad and Kibret, 2014; Beneduzi et al., 2012; Bhattacharyya and Jha, 2012; Kuiper et al., 2004; Mittal et al., 2017; Ryu et al., 2005).

The plant-microbe interaction is the fundamental determinant of soil fertility and plant health (Heidari and Golpayegani, 2012). The changing lifestyle and the essential dietary concern of the people considered fresh vegetables as an important diet in their daily consumption to maintain good health (Huxley et al., 2004). The trend of fresh vegetable consumption has grown stronger around the world (LópezGálvez et al., 2009). However, the safety concerns with regard to fungi, bacteria and other pathogens are emerging issues (Forghani and Oh, 2013; Seymour et al., 2002). Although, there exist several strain of pathogenic bacteria, Pseudomonas spp. have been widely reported as a beneficial species that are involved in healthy production of the plant (Ahemad and Kibret, 2014). However, to date, there is no report regarding the beneficial role of particularly $P$. koerensis MU2 strain. Therefore, the aim of the present study was to investigate the functional role of $P$. koreensis in order to evaluate growth and production of Chinese cabbage and lettuce.

\section{MATERIALS AND METHODS}

\section{Screening of the microbes}

The soil from different agricultural land was collected from Daegu, South Korea to isolate plant growth-promoting rhizospheric microbes. One gram of the soil sample was suspended in $9 \mathrm{~mL}$ of saline $(0.85 \% \mathrm{NaCl})$, diluted 5 -folds, and spread on a petri dish containing Luria-Bertani (LB; Difco, USA) agar medium from each 
diluted solution. The plated sample was cultured in an incubator at $30^{\circ} \mathrm{C}$ for 4 days The colonies of different microbial strains were distinguished and an individual strain from the different colonies was streaked on new LB plates and cultured in LB broth by incubating in a shaking incubator. Gibberellins and organic acid production ability of these strains were checked, and the ones with higher ability to produce organic acid and gibberellins' were selected, identified and employed for inoculation on plant experiment.

\section{Screening for gibberellins (GAs) detection}

The bioassay of the isolated microorganism to detect the absence or presence of GA was performed through the application of culture on a dwarf mutant waito- $C$ that lacks gibberellins. For these, rice seeds were surface sterilized with $2.5 \%$ sodium hypochlorite for $30 \mathrm{~min}$, rinsed with distilled water and incubated for $24 \mathrm{~h}$ with 20-ppm uni- conazole to obtain equally germinated seeds. After attaining two leaves stage, the CF 100 ul of MU2 was applied in rice seedlings. After 10 days, the rice shoot length, shoot fresh weight and shoot dry weight was recorded.

\section{Organic acids quantification}

The method described by Kang et al., (2015) was followed to quantify the organic acid. Briefly, bacterial culture was filtered through $0.22 \mu \mathrm{m}$ Millipore filter and 10 $\mu \mathrm{L}$ of filtrates were injected to HPLC (Model: Waters 600E) equipped with a Refractive Index Detector (Model: Waters 410). Column: RSpak KC-811(8.0 x $300 \mathrm{~mm}$ ), Eluent: $0.1 \% \mathrm{H}_{3} \mathrm{PO}_{4} / \mathrm{H} 2 \mathrm{O}$, Temperature: $40^{\circ} \mathrm{C}$ and Flow rate: $1.0 \mathrm{ml} / \mathrm{min}$

\section{Extraction and quantification of gibberellins produced by bacteria}

A protocol described by (Lee et al., 2015) was followed to extract and quantify GA content in bacterial culture. Briefly, an isolated bacterial strain MU2 was cultured in LB media in a shaking incubator for 5 days at $30^{\circ} \mathrm{C}$. The culture was centrifuged and the filtrate $(100 \mathrm{ml})$ was analyzed using GA extraction protocol (Lee et al. 1998). Three major ions of the supplemented $\left[{ }_{2} \mathrm{H}^{2}\right]$ GA interna standards (obtained from Prof. Lewis N. Mander, Australian National University, Canberra, Australia) and the exogenous GA were monitored simultaneously. Retention time was determined by using the hydrocarbon standards to calculate the Kovats retention indices value (Gaskin and MacMillan 1991). GAs was detected by using gas chromatography with a mass spectrometer $(6890 \mathrm{~N}$ network GC system, and 5973 network mass selective detector; Agilent Technologies).

\section{Identification and phylogenetic analysis of bacterial isolate MU2}

An isolated bacterial strain MU2 was identified on the basis of partial $16 \mathrm{~S}$ ribosomal rDNA sequence. The chromosomal DNA was isolated and the $27 \mathrm{~F}$ primer (5'-AGAGTTTGATC(AC)TGGCTCAG-3') and 1492R primer (5'-CGG (CT) TACCTTGTTACGACTT-3') were used for PCR amplification. The BLAST search program (http://www.ncbi.nlm.nih.gov/BLAST/) was used to find the nucleotide sequence homology of this bacterial isolate. The closely related nucleotide sequences were aligned by ClustalW and MEGA (version 6.0) software, and the neighbor-joining tree was generated. Bootstrap (1000 replications) was used for statistical support for the nodes in the phylogenetic tree.

\section{Experiment location, method, and design}

The experiment was conducted at the green house of Kyungpook Nationa Universtiy, Daegu, Korea located at longitude of $128.587655^{\circ} \mathrm{E}$ and latitude of $35.857655^{\circ} \mathrm{N}$. The bacterial culture of MU2 was incubated for 5 days at $30{ }^{\circ} \mathrm{C}$ on a shaking incubator at $200 \mathrm{rpm}$ in broth medium. The bacterial suspension was diluted in sterile distilled water to a final concentration of $10^{8} \mathrm{CFU} / \mathrm{ml}$. Chinese cabbage and lettuce seeds were purchased from Seminis Korea Co. (Korea), surface sterilized with sodium hypochlorite $(5 \%)$ for $10 \mathrm{~min}$, and thoroughly rinsed with autoclaved double distilled water (DDW). Seeds were sown in plastic tray containing horticultural soil and grown under the controlled greenhouse conditions $\left(30 \pm 2{ }^{\circ} \mathrm{C}\right)$. The composition of horticultural soil was as follows: peat moss (13$18 \%)$, perlite $(7-11 \%)$, coco-peat $(63-68 \%)$ and zeolite $(6-8 \%)$, with macro nutrients being $\mathrm{NH}_{4}{ }^{+} \sim 90 \mathrm{mg} / \mathrm{kg} ; \mathrm{NO}_{3} \sim 205 \mathrm{mg} / \mathrm{kg} ; \mathrm{P}_{2} \mathrm{O}_{5} \sim 350 \mathrm{mg} / \mathrm{kg}$ and $\mathrm{K}_{2} \mathrm{O} \sim 100$ $\mathrm{mg} / \mathrm{kg}$ (autoclaved three times). Two-week-old Chinese cabbage and lettuce seedlings (50 per treatments) were transplanted to the pot and treated with $5 \mathrm{ml}$ of bacterial culture $100 \mathrm{ppm}$. After 10 days, the growth attributes were recorded.

\section{Statistical analysis}

The present study was conducted in a completely randomized design (CRD) and the experiment was designed as Control and Treatment $(P$. koreensis) for both the crops, in which each treatment had 10 replication. The data were statistically analyzed with SAS 9.4 software (SAS Institute, Cary NC, USA). The mean values among treatments were compared using Duncan's multiple range test (DMRT) at $p \leq 0.05$.

\section{RESULTS AND DISCUSSION}

\section{Isolation, selection, and identification}

Through screening of soil sample from diverse agricultural land, various PGPR were isolated. The isolates were investigated based on the preliminary test of secondary metabolites production. The isolate that had the innate ability to produce the organic acid, and that promoted the growth of GA-deficient dwarf rice mutant Waito- $C$ was selected for further investigation. The phylogenetic analysis revealed that the sequence obtained by $16 \mathrm{~s}$ rDNA represent the microbes Pseudomonas koreensis. The isolate was registered in an NCBI with an accession number MU2KP 676116. The phylogenetic tree was constructed with gene sequence obtained in Blast Search Mega 6. Version(1000 bootstrap) Figure 1.

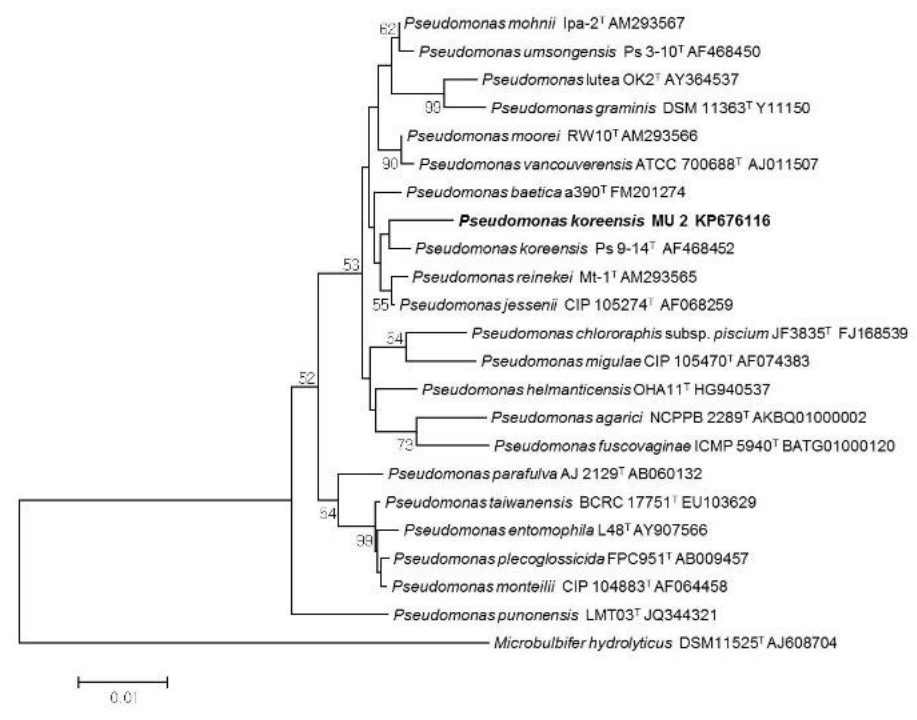

Figure 1 Phylogenetic tree based on the sequence obtained from $27 \mathrm{~F}$ and $1492 \mathrm{R}$ primers of $16 \mathrm{~S}$ rDNA of MU2(KP676116) and those of related bacteria Percentage confidence levels generated from 1000 bootstrap trees are indicated at each node.

\section{Gibberellins (GAs) detection}

The production of gibberellins through bacteria is widely reported (Hedden and Sponsel, 2015). The gibberellin acts as a signal molecule and also promotes plan growth (Bottini et al., 2004). In our study, the inoculation of the Pseudomonas koreensis MU2 culture significantly increased the shoot length by $27 \%$, shoot fresh weight by $29 \%$ and shoot dry weight by $33 \%$ of GA deficient mutant waito-c (Table 1). These results confirmed the ability of the microbes to produce GA.

Table 1 Effect of Pseudomonas koreensis on plant growth promoting characteristics of gibberellins deficient dwarf rice mutant waito-c.

\begin{tabular}{lccc}
\hline & $\begin{array}{c}\text { Shoot Length } \\
(\mathbf{c m})\end{array}$ & $\begin{array}{c}\text { Shoot Fresh } \\
\text { Weight }(\mathbf{g})\end{array}$ & $\begin{array}{c}\text { Shoot Dry Weight } \\
(\mathbf{g})\end{array}$ \\
\hline Control & $5.76 \pm 0.32^{\mathrm{b}}$ & $0.54 \pm 0.03^{\mathrm{b}}$ & $0.060 \pm 0.006^{\mathrm{b}}$ \\
MU2 & $7.32 \pm 0.33^{\mathrm{a}}$ & $0.70 \pm 0.07^{\mathrm{a}}$ & $0.082 \pm 0.005^{\mathrm{a}}$ \\
\hline
\end{tabular}

Results are expressed as mean $\pm \mathrm{SD}(\mathrm{n}=10)$ and significantly different at a $p<0.05$. Means sharing different superscript letter in a column indicate significant difference determined by $\operatorname{DMRT}(p \leq 0.05)$

\section{Gibberellins (GAs) quantification and analysis:}

In the present study, it was revealed that the bacteria were able to produce the gibberelins $\mathrm{GA}_{1}(1.92 \mathrm{ng} / 100 \mathrm{~mL})$ and $\mathrm{GA}_{3}(9.82 \mathrm{ng} / 100 \mathrm{~mL})$, in which $\mathrm{GA}_{3}$ was found significantly higher as compared to $\mathrm{GA}_{1}$ (Figure 2). Moreover, our results are consistent with the evidence that bacteria like Azospirillum brasilense, Azospirillum lipoferum, Acetobacter diazotropicus, Bacillus pumilus, Bacillus licheniformis are able to produce $\mathrm{GA}_{1}$ and $\mathrm{GA}_{3}$ (MacMillan, 2001). 


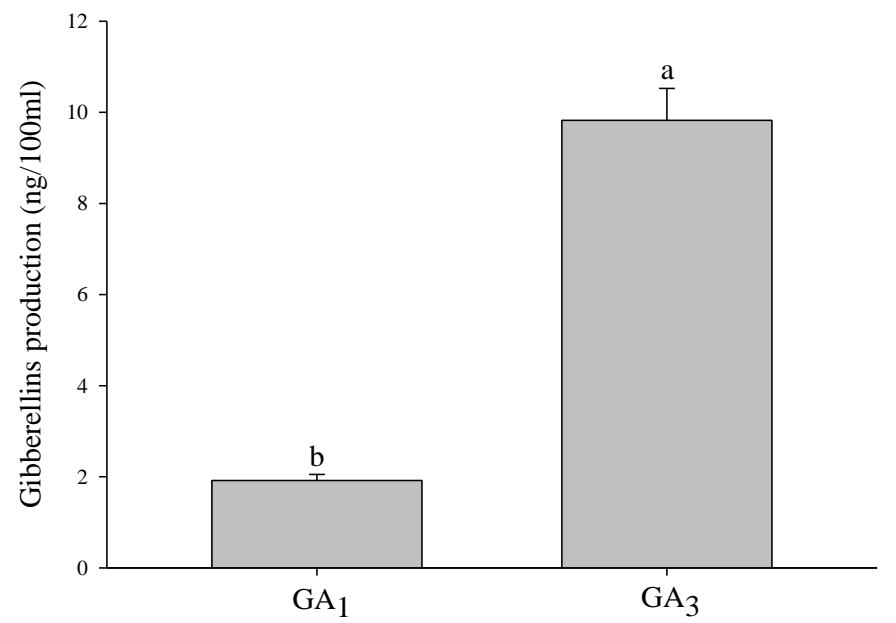

Figure 2 Quantification of gibberellins (GAs) content produced by Pseudomonas koreensis MU2 on the cultural filtrate. Bars represent means $\pm \mathrm{SD}(\mathrm{n}=3)$. Means followed by different letter indicate significant difference determined by DMRT $(p \leq 0.05)$

\section{Organic acid analysis}

Pseudomonas spp have been widely reported for their organic acid production ability (Berg, 2009; Rodríguez and Fraga, 1999; Vyas and Gulati, 2009). Our study revealed that the Pseudomonas koreensis could produce mallic acid (112.6 $\mathrm{ug} / \mathrm{mL})$, citric acid $(308.4 \mathrm{ug} / \mathrm{mL})$, and tartaric acid $(87.6 \mathrm{ug} / \mathrm{mL})$ among which citric acid was found significantly higher as compared to malic acid and tartaric acid (Figure 3). It has been reported that numerous species of PGPR have the ability to produce organic acids (Berg, 2009; Compant et al., 2005). These organic acids include citric acid, malic acid, oxalic acid, fumaric acid, acetic acid, butyric acid, succinic acid, valeric acid, piscidic acid, glycolic acid, formic acid, lactic acid, aconitic acid, pyruvic acid, malonic acid, tetronic acid, aldonic acid, glutaric acid, and erythronic acid (Ahemad and Kibret, 2014; Dakora and Phillips, 2002).

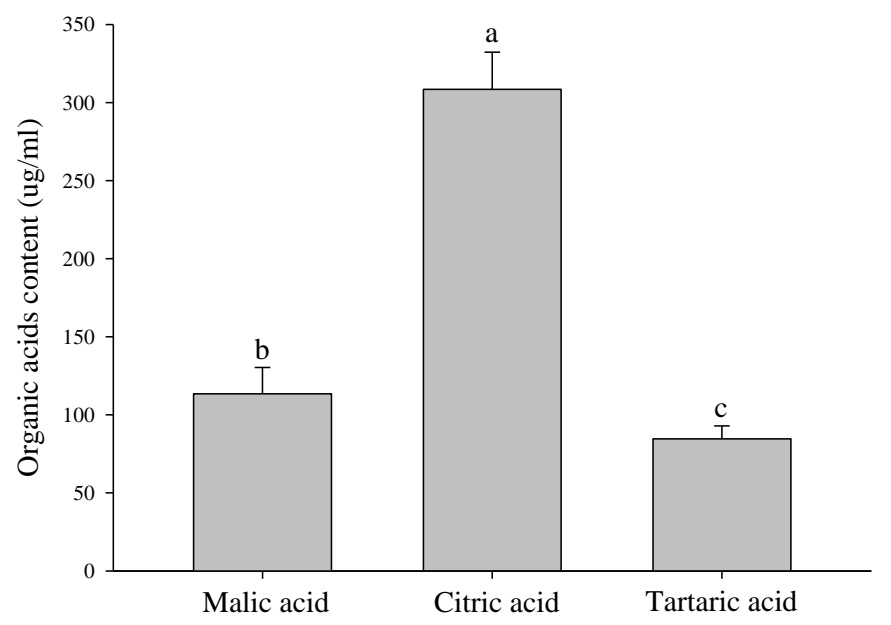

Figure 3 Quantification of Organic acid content produced by Pseudomonas koreensis MU2 on the cultural filtrate. Bars represent means $\pm \mathrm{SD}(\mathrm{n}=3)$. Means followed by different letter indicate significant difference determined by DMRT $(p \leq 0.05)$

\section{Effect of Bacterial culture on plant growth promoting attributes}

The Pseudomonas spp. exert a wide range of beneficial characteristics like highstress tolerance ability, detoxification of inorganic pollutants through immobilization/mobilization/oxidation/reduction/bioaccumulation and degradation of the xenobiotic compound and root colonization (Rajkumar et al., 2017). In our study, the inoculation of $P$. koreensis significantly increased the shoot length, root length, fresh biomass, dry biomass, and chlorophyll content of both the crops ( lettuce and Chinese cabbage) (Table 2). It have been reported that the Pseudomonas improved yield in wheat (Weller and Cook, 1986) and promoted growth in radish and potato (Kloepper et al., 1980). Pseudomonas (BA-8) improved the yield of sugarbeet (Çakmakçı et al., 2001). Similarly, the pseudomonas florescens improved growth in various crops like potato (Burr et al., 1978), Winter wheat (Weller and Cook, 1986), Tomato (Gagné et al., 1993), Highlush Blueberry(de Silva et al., 2000). Moreover, Pseudomonas spp. improved growth in lettuce, maize, barley, and wheat (Lucy et al., 2004). Furthermore, our results are strongly agreed by previous reports (Ullah et al., 2014 ;Kang et al., 2012; Joo et al., 2005;Joo et al., 2004), where gibberellin producing microorganism promoted growth in various plants.

Microorganisms are considered as the main source of organic acid content in soil (Adeleke et al., 2017). A Pseudomonas excrete a huge amount of organic acids which dissolve in the rhizosphere that solubilizes the insoluble phosphate and make available for plant uptake (Rajkumar et al., 2017). Organic acids play a significant role in mineralization and metal detoxification (Adeleke et al., 2017) as well as nutrient assimilation (Kashyap et al., 2017). Moreover, organic acid produced by Pseudomonas spp is involved in organic matter degradation through hydrolysis, acidogenesis, acetogenesis and methanogenesis (Adeleke et al., 2017). The organic acid produced by $P$. koreensis might have played role in metal solubilization, organic matter degradation, and nutrient assimilation to promote the growth in the plant.

Up to date, altogether 136 kinds of GAs have been reported to be isolated from bacteria, fungi and plants, out of which only $\mathrm{GA}_{1}, \mathrm{GA}_{3}$ and $\mathrm{GA}_{4}$ have been reported to be involved in the regulation of plant physiology and growth promotion (Bottini et al., 2004). As our results indicate that MU2 could produce the biologically active gibberelins $\mathrm{GA}_{1}$ and $\mathrm{GA}_{3}$, and organic acids like malic acid, citric acid, and tartaric acid, these secondary metabolites produced by microbes might have played a key role in the growth promotion of dwarf mutant Waito-C, Chinese cabbage and lettuce. Thus, Pseudomonas koreensis MU2 might be one of the efficient strains for commercial biofertilizer production in order to implement organic production.

Table 2 Effect of Pseudomonas korensis MU2 on growth promoting attributes on chinese cabbage and lettuce

\begin{tabular}{|c|c|c|c|c|c|}
\hline Treatments & $\begin{array}{l}\text { Shoot length } \\
\text { (cm/plant) }\end{array}$ & $\begin{array}{l}\text { Root length } \\
\text { (cm/plant) }\end{array}$ & $\begin{array}{l}\text { Fresh biomass } \\
\text { (g/plant) }\end{array}$ & $\begin{array}{l}\text { Dry biomass } \\
\text { (g/plant) }\end{array}$ & $\begin{array}{l}\text { Chlorophyll } \\
\text { (SPAD) }\end{array}$ \\
\hline \multicolumn{6}{|l|}{ Chinese cabbage } \\
\hline Control & $11.28 \pm 0.66^{\mathrm{b}}$ & $10.10 \pm 0.34^{b}$ & $4.02 \pm 0.16^{\mathrm{b}}$ & $0.41 \pm 0.01^{\mathrm{b}}$ & $31.88 \pm 1.45^{\mathrm{a}}$ \\
\hline P. koreensis MU2 & $12.82 \pm 0.38^{\mathrm{a}}$ & $10.96 \pm 0.59^{\mathrm{a}}$ & $4.62 \pm 0.43^{\mathrm{a}}$ & $0.47 \pm 0.06^{\mathrm{a}}$ & $32.28 \pm 1.49^{\mathrm{a}}$ \\
\hline \multicolumn{6}{|l|}{ Lettuce } \\
\hline Control & $16.82 \pm 1.09^{b}$ & $16.46 \pm 0.57^{\mathrm{b}}$ & $6.06 \pm 0.74^{\mathrm{b}}$ & $0.57 \pm 0.10^{\mathrm{b}}$ & $30.68 \pm 1.06^{\mathrm{a}}$ \\
\hline P. koreensis MU2 & $18.84 \pm 1.24^{\mathrm{a}}$ & $17.66 \pm 0.63^{\mathrm{a}}$ & $7.06 \pm 1.09^{\mathrm{a}}$ & $0.64 \pm 0.11^{\mathrm{a}}$ & $32.76 \pm 2.16^{\mathrm{a}}$ \\
\hline
\end{tabular}



CONCLUSION

Results are expressed as mean $\pm \mathrm{SD}(\mathrm{n}=10)$. Means sharing different superscript letter in a column indicate significant difference determined by DMRT ( $p \leq 0.05$ )

The anthropogenic activities leading to global climate change have been a serious problem in the current agricultural practice. Moreover, excessive use of pesticides and fertilizers has an adverse effect on the human as well as the ecological cycle. Application of plant growth promoting bacteria is considered an environmental friendly approach for sustainable and healthy production. The endogenous hormones and organic acid production by microbes play a key role in plant growth and development. In the present study, Pseudomonas koreensis MU2 was able to produce the biologically active gibberelline and organic acids and promoted the plant growth. Thus, it might be a cost-effective biofetilizer for the healthy growth and quality yield. Furthermore, our findings could lead to a better understanding of the plant-microbe interaction for future studies.

Acknowledgment: This research was supported by Basic Science Research Program through the National Research Foundation of Korea (NRF) funded by the Ministry of Education (2016R1D1A3B03931629).

\section{REFERENCES}

Adeleke, R., Nwangburuka, C., and Oboirien, B. (2017). Origins, roles and fate of organic acids in soils: A review. South African Journal of Botany 108, 393-406. http://dx.doi.org/https://doi.org/10.1016/j.sajb.2016.09.002

Ahemad, M., and Khan, M. S. (2012). Effects of pesticides on plant growth promoting traits of Mesorhizobium strain MRC4. Journal of the Saudi Society of Agricultural Sciences 11 ,

http://dx.doi.org/https://doi.org/10.1016/j.jssas.2011.10.001

Ahemad, M., and Kibret, M. (2014). Mechanisms and applications of plant growth promoting rhizobacteria: Current perspective. Journal of King Saud University Science 26, 1-20. http://dx.doi.org/https://doi.org/10.1016/j.jksus.2013.05.001

Beneduzi, A., Ambrosini, A., and Passaglia, L. M. (2012). Plant growth-promoting rhizobacteria (PGPR): their potential as antagonists and biocontrol agents Genetics and molecular biology 35, 1044-1051. http://dx.doi.org/10.1590/S141547572012000600020

Berg, G. (2009). Plant-microbe interactions promoting plant growth and health: perspectives for controlled use of microorganisms in agriculture. Applied microbiology and biotechnology 84, 11-18. https://doi.org/10.1007/s00253-009 2092-7

Bhattacharyya, P. N., and Jha, D. K. (2012). Plant growth-promoting rhizobacteria (PGPR): emergence in agriculture. World Journal of Microbiology and Biotechnology 28, 1327-1350. https://doi.org/10.1007/s11274-011-0979-9

Bloemberg, G. V., and Lugtenberg, B. J. (2001). Molecular basis of plant growth promotion and biocontrol by rhizobacteria. Current opinion in plant biology 4 343-350. https://doi.org/10.1016/S1369-5266(00)00183-7

Bottini, R., Cassan, F., and Piccoli, P. (2004). Gibberellin production by bacteria and its involvement in plant growth promotion and yield increase. Appl Microbiol Biotechnol 65, 497-503. http://dx.doi.org/10.1007/s00253-004-1696-1

Burr, T., Schroth, M., and Suslow, T. (1978). Increased potato yields by treatment of seedpieces with specific strains of Pseudomonas fluorescens and Pseudomonas putida [Bacterization]. Phytopathology. https://www.apsnet.org/publications/phytopathology/backissues/Documents/1978 Articles/Phyto68n09_1377.pdf

Çakmakçı, R., Kantar, F., and Sahin, F. (2001). Effect of N2-fixing bacteria inoculations on yield of sugar beet and barley. Journal of Plant Nutrition and Soil Science 164, 527-531. https://doi.org/10.1002/15222624(200110)164:5<527::AID-JPLN527>3.0.CO;2-1

Compant, S., Duffy, B., Nowak, J., Clément, C., and Barka, E. A. (2005). Use of plant growth-promoting bacteria for biocontrol of plant diseases: principles, mechanisms of action, and future prospects. Applied and environmental microbiology 71, 4951-4959.

Dakora, F. D., and Phillips, D. A. (2002). Root exudates as mediators of mineral acquisition in low-nutrient environments. In "Food Security in Nutrient-Stressed Environments: Exploiting Plants' Genetic Capabilities", pp. 201-213. https://doi.org/10.1007/978-94-017-1570-6 23

de Silva, A., Patterson, K., Rothrock, C., and Moore, J. (2000). Growth promotion of highbush blueberry by fungal and bacterial inoculants. HortScience 35, 12281230. https://doi.org/10.21273/HORTSCI.35.7.1228

Forghani, F., and Oh, D.-H. (2013). Hurdle enhancement of slightly acidic electrolyzed water antimicrobial efficacy on Chinese cabbage, lettuce, sesame leaf and spinach using ultrasonication and water wash. Food Microbiology 36, 40-45. http://dx.doi.org/https://doi.org/10.1016/j.fm.2013.04.002

Gagné, S., Dehbi, L., Le Quéré, D., Cayer, F., Morin, J.-L., Lemay, R., and Fournier, N. (1993). Increase of greenhouse tomato fruit yields by plant growthpromoting rhizobacteria (PGPR) inoculated into the peat-based growing media Soil Biology and Biochemistry 25, 269-272. https://doi.org/10.1016/00380717(93)90038-D

Gutiérrez-Mañero, F. J., Ramos-Solano, B., Probanza, A., Mehouachi, J., R Tadeo, F., an d Talon, M. (2001). The plant-growth-promoting rhizobacteria Bacillus

pumilus and Bacillus licheniformis produce high amounts of physiologically active gibberellins. Physiologia Plantarum 111, 206-211. https://doi.org/10.1034/j.13993054.2001.1110211.x

Hedden, P., and Sponsel, V. (2015). A Century of Gibberellin Research. Journal of Plant Growth Regulation 34, 740-760. http://dx.doi.org/10.1007/s00344-0159546-1

Heidari, M., and Golpayegani, A. (2012). Effects of water stress and inoculation with plant growth promoting rhizobacteria (PGPR) on antioxidant status and photosynthetic pigments in basil (Ocimum basilicum L.). Journal of the Saudi Society of Agricultural Sciences 11, 57-61. https://doi.org/10.1016/j.jssas.2011.09.001.

Huxley, R., Lean, M., Crozier, A., John, J., and Neil, H. (2004). Effect of dietary advice to increase fruit and vegetable consumption on plasma flavonol concentrations: results from a randomised controlled intervention trial. Journal of $\begin{array}{llll}\text { Epidemiology } \quad \text { C } & \text { Health } & \text { 58, 288-289. }\end{array}$ http://dx.doi.org/10.1136/jech.2003.014274

Islam, F., Yasmeen, T., Ali, Q., Ali, S., Arif, M. S., Hussain, S., and Rizvi, H. (2014). Influence of Pseudomonas aeruginosa as PGPR on oxidative stress tolerance in wheat under Zn stress. Ecotoxicology and Environmental Safety 104, 285-293. https://doi.org/10.1016/j.ecoenv.2014.03.008

Joo, G. J., Kim, Y. M., Kim, J. T., Rhee, I. K., Kim, J. H., and Lee, I. J. (2005) Gibberellins-producing rhizobacteria increase endogenous gibberellins content and promote growth of red peppers. $J$ Microbiol 43, 510-5. https://doi.org/10.1023/B:BILE.0000019555.87121.34

Joo, G. J., Kim, Y. M., Lee, I. J., Song, K. S., and Rhee, I. K. (2004). Growth promotion of red pepper plug seedlings and the production of gibberellins by Bacillus cereus, Bacillus macroides and Bacillus pumilus. Biotechnol Lett 26, 487 91. https://doi.org/10.1023/B:BILE.0000019555.87121.34

Kang, S. M., Radhakrishnan, R., You, Y. H., Khan, A. L., Park, J. M., Lee, S. M. \& Lee, I. J. (2015). Cucumber performance is improved by inoculation with plant growth-promoting microorganisms. Acta Agriculturae Scandinavica, Section BSoil \& Plant Science, 65(1), 36-44. https://doi.org/10.1080/09064710.2014.960889

Kang, S.-M., Radhakrishnan, R., Khan, A. L., Kim, M.-J., Park, J.-M., Kim, B.-R., Shin, D.-H., and Lee, I.-J. (2014). Gibberellin secreting rhizobacterium, Pseudomonas putida H-2-3 modulates the hormonal and stress physiology of soybean to improve the plant growth under saline and drought conditions. Plant $\begin{array}{llll}\text { Physiology and } \quad \text { Biochemistry } & 84, & 115-124\end{array}$ http://dx.doi.org/https://doi.org/10.1016/j.plaphy.2014.09.001

Kang, S.-M., Waqas, M., Hamayun, M., Asaf, S., Khan, A. L., Kim, A.-Y., Park, Y.-G., and Lee, I.-J. (2017). Gibberellins and indole-3-acetic acid producing rhizospheric bacterium Leifsonia xyli SE134 mitigates the adverse effects of copper-mediated stress on tomato. Journal of Plant Interactions 12, 373-380 http://dx.doi.org/10.1080/17429145.2017.1370142

Kang, S. M., Khan, A. L., Hamayun, M., Hussain, J., Joo, G. J., You, Y. H., Kim, J. G., and Lee, I. J. (2012). Gibberellin-producing Promicromonospora sp. SE188 improves Solanum lycopersicum plant growth and influences endogenous plant hormones. J Microbiol 50, 902-9. https://doi.org/10.1007/s12275-012-2273-4 Karlidag, H., Yildirim, E., Turan, M., Pehluvan, M., and Donmez, F. (2013). Plant growth-promoting rhizobacteria mitigate deleterious effects of salt stress on strawberry plants (Fragaria $\times$ ananassa). Hortscience 48, 563-567.

https://doi.org/10.21273/HORTSCI.48.5.563

Kashyap, A. S., Pandey, V. K., Manzar, N., Kannojia, P., Singh, U. B., and Sharma, P. (2017). Role of Plant Growth-Promoting Rhizobacteria for Improving Crop Productivity in Sustainable Agriculture. In "Plant-Microbe Interactions in Agro-Ecological Perspectives", pp. 673-693. Springer.

https://doi.org/10.1007/978-981-10-6593-4_28

Kloepper, J., Schroth, M., and Miller, T. (1980). Effects of rhizosphere colonization by plant growth-promoting rhizobacteria on potato plant development and yield. Phytopathology 70, 1078-1082.

Kuiper, I., Lagendijk, E. L., Bloemberg, G. V., and Lugtenberg, B. J. (2004) Rhizoremediation: a beneficial plant-microbe interaction. Molecular plant microbe interactions 17, 6-15. https://doi.org/10.1094/MPMI.2004.17.1.6

Kwon, S. W., Kim, J. S., Park, I. C., Yoon, S. H., Park, D. H., Lim, C. K., \& Go, S. J. (2003). Pseudomonas koreensis sp. nov., Pseudomonas umsongensis sp. nov. and Pseudomonas jinjuensis sp. nov., novel species from farm soils in Korea. International journal of systematic and evolutionary microbiology, 53(1), 21-27 doi: 10.1099/ijs.0.02326-0

Lee I-J, Foster KR, Morgan PW. 1998. Photoperiod control of gibberellin levels and flowering in sorghum. Plant physiology. 116(3):1003-1011. https://doi.org/10.1104/pp.116.3.1003

Lee, K.-E., Radhakrishnan, R., Kang, S.-M., You, Y.-H., Joo, G.-J., Lee, I.-J., Ko, J.-H., and Kim, J.-H. (2015). Enterococcus faecium LKE12 Cell-Free Extract Accelerates Host Plant Growth via Gibberellin and Indole-3-Acetic Acid Secretion. J. Microbiol. Biotechnol 25, 1467-1475 http://dx.doi.org/10.4014/jmb.1502.02011 
Lim, J.-H., and Kim, S.-D. (2013). Induction of drought stress resistance by multifunctional PGPR Bacillus licheniformis $\mathrm{K} 11$ in pepper. The plant pathology journal 29, 201. doi: 10.5423/PPJ.SI.02.2013.0021

López-Gálvez, F., Allende, A., Selma, M. V., and Gil, M. I. (2009). Prevention of Escherichia coli cross-contamination by different commercial sanitizers during washing of fresh-cut lettuce. International Journal of Food Microbiology 133 167-171. https://doi.org/10.1016/i.ijfoodmicro.2009.05.017

Lucy, M., Reed, E., and Glick, B. R. (2004). Applications of free living plant growth-promoting rhizobacteria. Antonie van leeuwenhoek 86, 1-25. https://doi.org/10.1023/B:ANTO.0000024903.10757.6e

Lugtenberg, B., and Kamilova, F. (2009). Plant-growth-promoting rhizobacteria. Annual review of microbiology 63, 541-556.

https://doi.org/10.1146/annurev.micro.62.081307.162918

MacMillan, J. (2001). Occurrence of Gibberellins in Vascular Plants, Fungi, and $\begin{array}{llll}\text { Bacteria. } J \text { Plant Regul 20, 387-442. } & \text { Growth }\end{array}$ http://dx.doi.org/10.1007/s003440010038

Maheshwari, D. K. (2011). "Bacteria in agrobiology: crop ecosystems," Springer Science \& Business Media.

Mittal, P., Kamle, M., Sharma, S., Choudhary, P., Rao, D. P., and Kumar, P. (2017). 22 Plant Growth-Promoting Rhizobacteria (PGPR): Mechanism, Role in Crop Improvement and Sustainable Agriculture. Advances in PGPR Research, 386.

Muleta, D., Assefa, F., Börjesson, E., and Granhall, U. (2013). Phosphatesolubilising rhizobacteria associated with Coffea arabica L. in natural coffee forests of southwestern Ethiopia. Journal of the Saudi Society of Agricultural Sciences 12, 73-84. http://dx.doi.org/https://doi.org/10.1016/j.jssas.2012.07.002

Park, Y.-G., Mun, B.-G., Kang, S.-M., Hussain, A., Shahzad, R., Seo, C.-W., Kim, A.-Y., Lee, S.-U., Oh, K. Y., and Lee, D. Y. (2017). Bacillus aryabhattai SRB02 tolerates oxidative and nitrosative stress and promotes the growth of soybean by modulating the production of phytohormones. PloS one 12, e0173203 https://doi.org/10.1371/journal.pone.0173203

Podile, A. R., and Kishore, G. K. (2007). Plant growth-promoting rhizobacteria. In "Plant-associated bacteria", pp. 195-230. https://doi.org/10.1007/978-1-4020 4538-7_6

Rajkumar, M., Bruno, L. B., and Banu, J. R. (2017). Alleviation of environmental stress in plants: The role of beneficial Pseudomonas spp. Critical Reviews in Environmental Science and Technology 47, 372-407. https://doi.org/10.1080/10643389.2017.1318619

Rodríguez, H., and Fraga, R. (1999). Phosphate solubilizing bacteria and their role in plant growth promotion. Biotechnology advances 17, 319-339. https://doi.org/10.1016/S0734-9750(99)00014-2

Ryu, C.-M., Hu, C.-H., Locy, R. D., and Kloepper, J. W. (2005). Study of mechanisms for plant growth promotion elicited by rhizobacteria in Arabidopsis thaliana. Plant and Soil 268, 285-292. https://doi.org/10.1007/s11104-004-0301-

Seymour, I., Burfoot, D., Smith, R., Cox, L., and Lockwood, A. (2002). Ultrasound decontamination of minimally processed fruits and vegetables. International journal of food science \& technology 37, 547-557. https://doi.org/10.1046/j.13652621.2002.00613.x

Ullah, I., Khan, A. R., Jung, B. K., Khan, A. L., Lee, I. J., and Shin, J. H. (2014) Gibberellins synthesized by the entomopathogenic bacterium, photorhabdus temperata M1021 as one of the factors of rice plant growth promotion. Journal of Plant Interactions 9, 775-782. http://dx.doi.org/10.1080/17429145.2014.942956

Vurukonda, S. S. K. P., Vardharajula, S., Shrivastava, M., \& SkZ, A. (2016). Enhancement of drought stress tolerance in crops by plant growth promoting rhizobacteria. Microbiological research, 184, 13-24 https://doi.org/10.1016/j.micres.2015.12.003

Vyas, P., and Gulati, A. (2009). Organic acid production in vitro and plant growth promotion in maize under controlled environment by phosphatesolubilizing fluorescent Pseudomonas. BMC microbiology 9, 174. https://doi.org/10.1186/1471-2180-9-174

Weller, D. M., and Cook, R. J. (1986). Increased growth of wheat by seed treatments with fluorescent Pseudomonads, and implications of Pythium control. Canadian Journal of Plant Pathology 8, 328-334. https://doi.org/10.1080/07060668609501808

Zaidi, A., Khan, M., Ahemad, M., and Oves, M. (2009). Plant growth promotion by phosphate solubilizing bacteria. Acta microbiologica et immunologica Hungarica 56, 263-284.https://doi.org/10.1556/AMicr.56.2009.3.6 